FOLIA SCANDINAVICA VOL. 18 POZNAŃ 2015 DOI: $10.1515 / \mathrm{fsp}-2015-0016$

DE DE GRUYTER OPEN

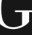

PRESSto. $\pm M U$

\title{
HVOR KONSERVATIVE ER POLSKE NORSKSTUDENTER I SIN SPRÅKBRUK?
}

HUNKJØNNSMARKERING I NORSKINNLÆRERES TEKSTPRODUKSJON.

\section{PAULINA HORBOWICZ}

Adam Mickiewicz University, Poznań

ABSTRACT. The paper examines the phenomenon of the feminine gender, which in Bokmål is optional. The choice between the masculine and feminine forms is nevertheless not without meaning. It has been proved that if some nouns appear in feminine form earlier in a text, it implies the use of feminine gender on other nouns (Dyvik, 2012). Hence, the appearance of feminine marking on different words is mutually related, and may be shown to be consistent or not. The paper analyses texts written by Polish students of Norwegian on three different levels of language command $(\mathrm{A} 2, \mathrm{~B} 2 / \mathrm{C} 1$ and $\mathrm{C} 2+)$ and investigates their use of feminine marking. The results show that the feminine gender is most often used by beginner learners, which confirms the initial hypothesis. Contrary to expectations, the most advanced students show inconsistency in their choice of feminine marking at least as often as beginner learners. The general conclusion is that the majority of Norwegian learners are not fully aware of the implications which come with the use of the feminine gender.

\section{SKRIFTSPRÅKET I NORGE ${ }^{1}$}

Takket være historiske og språkpolitiske grunner (Dyvik, 2012, jf. Jahr, 1994) er det to normer i norsk skriftspråk, bokmål og nynorsk. De to normene er likestilte, noe som innebærer at situasjonen ikke kan klassifiseres som et tilfelle av diglossi. Norsk kan heller omtales som et multinorm språk (Trudgill, 1997) der begge varianter gjelder for det samme territoriet (til forskjell fra andre multinorm språk som for eksempel engelsk,

\footnotetext{
${ }^{1}$ Denne delen er en bearbeidet framstilling presentert i Horbowicz (2011).
} 
der ulike varianter brukes i ulike land). Dette innebærer også at begge skriftspråksnormalene bygger på "a single set of nonstandard dialects" (Trudgill, 1997:157). Begge skriftnormalene inneholder dessuten en rekke varianter:

I tillegg har vi hos oss systemet med "hovedformer" og "sideformer", noe som er spesielt for den norske språknormeringa. Hovedformer inngår i den såkalte "læreboknormalen", og den er ei trangere norm enn "rettskrivinga", som også inneholder sideformer ("klammeformer"). Læreboknormalen skal i dag brukes i lærebøker som godkjennes språklig til bruk i skolen, og i statlig tjeneste. Rettskrivinga kan brukes av elever i skolen, slik at de står fritt i sitt valg av former som fins i ordlister. (Omdal, 1999:6)

Rettskrivingen tillater altså et mangfold av valgmuligheter når det gjelder bøyningsformer (for eksempel valg at et- eller a-endelse for svake verb av 1.gruppe) og stammeformer ${ }^{2}$ (bruk av diftong i alene eller aleine). For eksempel har setningen:

(1) De lavtlønte sykehjemsansatte ble helt utmattet og slukket tørsten med den surnete fløtemelken.

165.888 mulige stavemåter på bokmål (Rosén \& de Smedt, 2000:217)! Tilsynelatende er alle disse variantene like sannsynlige, for ordbøkene legger ingen forbehold på hvilke former som kan brukes ved siden av hverandre i en setning (eller ett ord, i tilfelle sammensetninger). I praksis er likevel folks skriftlige språkbruk styrt av uformulerte normer fordi "mange språkbrukere har tilnærmet sammenfallende intuisjoner om hvordan formvalgene henger sammen i språklig og stilistisk konsistente tekster" (Dyvik, 2009:19). I tilfelle den ovennevnte setningen kan man oppgi eksempler på usannsynlige variasjoner der:

radikale og konservative ordformer [er] kombinert hulter til bulter på en måte som ingen bokmålsbrukere vil finne naturlig. Men det er ikke bare sammenstillingen av ordformer som virker rart. Også noen av ordformene i seg selv vil de fleste reagere på, f.eks. lågtlønnede, der den radikale roten låg kombineres med den konservative endelsen -ede. (Rosén \& de Smedt, 2000:217)

I praksis betyr det at det finnes visse implikasjonsforhold mellom variantvalg, dvs. at bruk av en form fører med seg visse begrensninger på hvilke former som senere kan dukke opp i teksten. Slike implikasjonsforhold mellom formvalg er ensidige og fører til at det oppstår et mønster

${ }^{2}$ Dyvik (2012:193) argumenterer mot bruk av den vanlige termen stavevariant (engelsk 'spelling variant') til fordel for stammeformer ('stem forms'). 
for subvarieteter innenfor begge skriftsnormalene (Dyvik, 2009:20). Disse subvarietetene får ofte betegnelser og blir oppfattet som et slags kontinuum, for eksempel "fra sterkt konservativt bokmål (til dels utafor offisiell rettskriving) via bokmål med tilnærmingsformer og nynorsk med tilnærmingsformer og til konservativt nynorsk (til dels utafor offisiell rettskriving)" (Omdal, 1999:6). I sitt stavekontrollprogram SCARRIE opererer Rosén \& de Smedt med 4 "stiler" i bokmål som en skribent kan velge mellom: nøytralt, konservativt, radikalt og læreboksnormalen (Rosén \& de Smedt, 2000:217) ${ }^{3}$. Imidlertid er kun én av disse stilene helhetlig beskrevet (læreboksnormalen), mens de tre andre er blitt kodet basert på intuisjonen til norske morsmålstalere. Samtidig påstås det at:

Radikalt bokmål og konservativt bokmål er nokså velkjente begreper, selv om norske ordbøker ikke inneholder informasjon om ordenes stilverdi. I kodingen av disse stilene har vi forsøkt å holde oss til det folk vil oppfatte som typisk for dem. (Rosén \& de Smedt, op.cit.).

På den annen side oppfatter Dyvik (2012:201) radikalt bokmål som en sum av potensielle avvik fra moderat bokmål, heller enn en identifiserbar varietet. Det er nemlig ikke blitt empirisk unders $\emptyset$ kt og utførlig beskrevet hvilke formkombinasjoner som danner mønsteret for hver av disse subvarietetene. Konnotasjonene de framkaller er heller ikke entydige. Dyvik (ibid.:194) skriver for eksempel at bruken av visse former kan romme politisk innhold, men den kan samtidig gi teksten et gammeldags preg.

Med andre ord kan man si at norsk er et multi-mulitnorm språk, for å bruke Trudgills (1997) begrep. Det er blandede meninger om hva det i praksis betyr for språkbrukere. Sandøy (2009:221ff.) mener at denne situasjonen har langt flere fordeler enn ulemper, og peker på tallrike studier som underbygger påstanden om at valgfriheten ikke fører til nedsatt skriveevne hos norske elever, og at den tvert imot gir pedagogiske fordeler, for den styrker "gjenkjenning, identitet og kulturell sjølvtillit" (Sandøy, ibid.:222). Den trange skriftspråksnormeringen oppfatter han som udemokratisk. På linje med dette argumentet kan man se på de private rettskrivningsordlistene til de landsdekkende avisene (for eksempel Aftenposten, jf. Eek, 2009) som en potensiell trussel mot demokrati. Det positive synet på språklig mangfold er altså den vanligste ideologien i Norge nå for tida (Tønnessen, 2009:242). På den annen side påstås det at "valfridom og heterogen norm er elitistisk" (ibid.:250), og at til og med erfarne skribenter faktisk sliter med å beholde

${ }^{3}$ Samtidig fungerer også begrepene riksmål og moderat bokmål (jf. Tønnessen 2009:247). For en utlending er det ikke ubegrunnet å spørre hvor grensen mellom riksmål og konservativt bokmål går, eller hvor moderat og nøytralt bokmål plasserer seg i forhold til bokmål med tilnærmingsformer. 
konsekvensen i formvalgene sine. En utdypende diskusjonen om dette emnet ligger utenfor artikkelens rammer. Det er likevel ingen tvil om at valgfriheten og dens følge, dvs. de ukodifiserte subvarietetene av skriftspråksnormen, ikke gjør det norske skriftspråket lett å tilegne for utenlandske innlærere. Når man legger til at det i norsk mangler en offisiell talespråksnormering ${ }^{4}$, virker korrekt norsk språkbruk tilnærmet uoppnåelig for andrespråksbrukere. Denne teksten studerer hvordan norskstudentene i Polen klarer å navigere seg gjennom det norske språkets hav, eller nærmere sagt ett av dets bukter, nemlig bruk av hunkjønnsmarkører.

\section{GENUS I NORSK OG NORSK SOM ANDRESPRÅK}

Norsk oppfattes generelt som et språk med et trekjønnssystem (Faarlund, Lie \& Vannebo, 1997:149). Det er likevel forskjeller på hvor sterkt dette systemet er i talespråket og de to skriftspråksnormene. Dialektene og nynorsk har et utbygd trekjønnssystem, mens det i bokmål forekommer en variasjon mellom trekjønnssystemet og tokjønnssystemet, der maskulinum og femininum danner felleskjønn (op.cit.:150). Samtidig omtaler Vagstein (2009) bokmål som et språk med fem genus, der inanimat og animat danner en separat gruppe blant både maskulinum og femininum:

\begin{tabular}{|ccccc|}
\hline GENUS & $\begin{array}{c}\text { ENTALL } \\
\text { UBESTEMT }- \\
\text { PRONOMEN }\end{array}$ & $\begin{array}{c}\text { ENTALL } \\
\text { BESTEMT }\end{array}$ & $\begin{array}{c}\text { FLERTALL } \\
\text { UBESTEMT }\end{array}$ & $\begin{array}{c}\text { FLERTALL } \\
\text { BESTEMT }\end{array}$ \\
\hline $\begin{array}{c}\text { ANIMAT } \\
\text { MASKULINUM }\end{array}$ & en gutt - han & gutten & gutter & guttene \\
\hline $\begin{array}{c}\text { INANIMAT } \\
\text { MASKULINUM }\end{array}$ & en hatt - den & hatten & hatter & hattene \\
\hline $\begin{array}{c}\text { ANIMAT } \\
\text { FEMININUM }\end{array}$ & ei jente - hun & jenta & jenter & jentene \\
\hline $\begin{array}{c}\text { INANIMAT } \\
\text { FEMININUM }\end{array}$ & ei bok - den & boka & bøker & bøkene \\
\hline NØYTRUM & et bord - det & bordet & bord & bordene \\
\hline
\end{tabular}

(Tab.1) Genussystemet i moderne bokmål.

I tab. 1 kan man imidlertid se at genuskategorien holder seg sterkest i entall, og at forskjellen mellom hankjønn og hunkjønn viskes bort i flertall. Den er heller ikke synlig i formen av de fleste possessive og determinative pronomener:

${ }^{4}$ Selv om noen hevder at man i praksis kan operere med en talespråksnorm i Norge, jf. Jahr \& Mæhlum 2009. 


\begin{tabular}{|lcccc|}
\hline & $\begin{array}{c}\text { ENTALL } \\
\text { MASKULINUM }\end{array}$ & $\begin{array}{c}\text { FLERTALL } \\
\text { MASKULINUM }\end{array}$ & $\begin{array}{c}\text { ENTALL } \\
\text { FEMININUM }\end{array}$ & $\begin{array}{c}\text { FLERTALL } \\
\text { FEMININUM }\end{array}$ \\
\hline & en gutt & gutter & ei jente & jenter \\
\hline $\begin{array}{l}\text { POSSESSIVT PRONOMEN } \\
\text { 1. PERSON ENTALL }\end{array}$ & gutten min & guttene mine & jenta mi & jentene mine \\
\hline $\begin{array}{l}\text { POSSESSIVT PRONOMEN } \\
\text { 3. PERSON ENTALL }\end{array}$ & gutten hans & guttene hans & jenta hans & jentene hans \\
\hline $\begin{array}{l}\text { POSSESSIVT PRONOMEN } \\
\text { 1. PERSON FLERTALL }\end{array}$ & gutten vår & guttene våre & jenta vår & jentene våre \\
\hline $\begin{array}{l}\text { DETERMINATIVT } \\
\text { PRONOMEN }\end{array}$ & denne gutten & disse guttene & denne jenta & disse jentene \\
\hline
\end{tabular}

(Tab.2) Maskulinums- og femininumsformer av possessive og determinative pronomener.

Det ligger utenfor artikkelens rammer å drøfte spørsmålet om genus i norsk videre. Det er likevel viktig å påpeke at hunkjønnsmarkører utgjør en viktig variasjonskilde i norske tekster, og at denne "variasjonen er avhengig av både dialektale, sosiolektiske, stilistiske og språkpolitiske forhold" (Faarlund m.fl., 1997:151). Tradisjonelt sett er en ekstensiv bruk av feminine markører oppfattet som radikalt bokmål. En balansert bruk av både feminine og maskuline markører klassifiseres som moderat, mens stort sett manglende bruk av feminine endelser plasserer språket i den andre enden av skalaen, dvs. konservativt bokmål ${ }^{5}$. Samtidig er det sånt at substantiver korrelerer med hverandre i forhold til hvilke former som dukker opp i samme tekst (Dyvik, 2009). Basert på en stor korpusundersøkelse har Dyvik (2012) pekt på hvilke former som kan oppfattes som et markert eller umarkert formvalg og lagt fram et system av implikasjonsforhold mellom dem. Det gjengis i en noe forenklet form i tabell 3 .

\begin{tabular}{|c|c|c|}
\hline & A-FORMER & EN-FORMER \\
\hline \multirow{4}{*}{ MARKERT } & kvinna utfordringa løsninga & konen \\
\cline { 2 - 3 }$\downarrow$ & makta grensa kirka & gaten fremtiden boken \\
$\downarrow$ & meldinga treninga dattera & døren luften \\
\cline { 2 - 3 } IMPLIKASJONSFORHOLD & sida tida natta helga & siden tiden natten helgen \\
\cline { 2 - 3 }$\downarrow$ & lufta avisa døra framtida & makten grensen \\
$\downarrow$ & boka & \\
$\downarrow$ & uka jenta & $\begin{array}{c}\text { kvinnen datteren moren } \\
\text { teksten prisen pressen } \\
\text { UMARKERT }\end{array}$ \\
\cline { 2 - 3 } & kona & $\begin{array}{c}\text {-ing+en } \\
\text {-het+en }\end{array}$ \\
\hline
\end{tabular}

(Tab.3) Implikasjonsforhold mellom de ulike bundne hunkjønnsformer, forenklet etter Dyvik (2012).

${ }^{5}$ Her må man også nevne den bergenske varianten av bokmål som gjengir det tokjønnete systemet fra talemålet i skrift, uten at det nødvendigvis har andre konnotasjoner. 
Dersom man bruker en a- eller en-form på ett av de ordene som står фverst i tabellen, er det høyst sannsynlig at ordene som står nedenfor også vil få henholdsvis en a- eller en-endelse. For eksempel, hvis formen meldinga forekommer i teksten, er det forventet at også ordene natt, $d \phi r$ og uke vil få a-endelse. Implikasjonsforholdet gjelder ikke for ordene som står ovenfor, dvs. at bruken av formen meldinga ikke impliserer a-endelse på ordet kvinne. Samme prinsipp gjelder for de maskuline formene. Unders $\varnothing$ kelsen til Dyvik har en begrensning $i$ at den kartlegger kun 60 lemma som ofte nok dukket opp i de analyserte avistekstene, og som man kunne bevise implikasjonsforhold mellom.

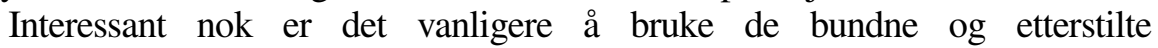
hunkjønnsmarkørene (-a-endelse og etterstilt possessivt pronomen, for eksempel mi) enn de foranstilte (den ubestemte artikkelen ei og foranstilt possessivt pronomen) (Faarlund m.fl., 1997:152). Det er dermed ikke utelukket å finne følgende kombinasjon i samme tekst: en bok, min bok, boka mi.

Genus i norsk som andrespråk har hittil ikke blitt undersøkt i noen stor grad. Glahn m.fl. (2001) fant ut at andrespråksinnlærere av nordiske språk mestrer genus sist av alle nominale kategorier (unntatt bestemthetsbøyning som ikke ble undersøkt). I sin masteravhandling refererer Ragnhildstveit (2009) til Uri (2001, etter Ragnhildstveit 2009:42-43), der det påvises at barn med tyrkisk som morsmål bruker maskulinum som defaultgenus, mens femininum kan sees på som noe underrepresentert. Denne påstanden bekreftes i studien til Ragnhildstveit (ibid.), der norskinnlærere med fem forskjellige morsmål (tysk, nederlandsk, spansk, vietnamesisk og engelsk) forenkler det grammatiske systemet ved en begrenset bruk av femininum, og bruker hankjønn som defaultgenus. Denne studien fokuserer imidlertid på feil i genustildelingen, og dermed måler den ikke hvor stor andel av de potensielt feminine ord er blitt tildelt hunkjønn i tekstene. Med andre ord blir begge alternativene uken og $u k a$ registrert som korrekt genustildeling. Ragnhildstveit har likevel fătt bekreftet en forholdsvis liten bruk av hunkjønnsmarkerte substantiver blant alle brukte substantiver. Andelen ligger på $4 \%$ av hos den engelske morsmålsgruppen (som bruker minst hunkjønn av alle undersøkte nasjonaliteter) og 13\% hos den vietnamesiske (som bruker mest hunkjønn, disse tallene gjelder for bestemt form av substantivet, ibid. 88-90). Dessuten fant hun ut av innlærere heller bruker hunkjønnsmarkører i bestemt form enn ubestemt pronomen $e i$, og at "i hele datamaterialet er 21,58\% av den feminine genustildelingen gjort på semantisk grunnlag, dvs. ved substantiv av typen mor, datter, jente, kone, venninne, dame osv." (ibid:90).

\section{FORSKNINGSSPØRSMÅL, MATERIALE OG HYPOTESER}

Som allerede antydet har denne studien som formål å undersøke de polske norskstudentenes bruk av hunkjønnsmarkører på ulike nivår av deres målspråkbeherskelse. Hovedtyngden i studien ligger altså i hvilke former som 
finnes i studentenes tekstproduksjon. Samtidig er hunkjønnsmarkører som oftest framstilt som valgfrie og avhengige kun av den enkelte språkbrukeren, og det er lite bevissthet om hvor intrikate reglene for deres anvendelse er. Derfor bestemte jeg meg også for å måle studentenes erklærte språkbruk og deres bevissthetsnivå om bruk av hunkjønnsmarkører ved hjelp av en spørreundersøkelse (vedlegg 1). Studentene ble bedt om å bestemme hvilke hunkjønnsmarkerte former de bruker i sine tekster, og til å vurdere setningene som inneholdt forskjellige kombinasjoner av substantiver i hunkjønn. Noen av disse setningene var i samsvar med implikasjonsforholdene indikert av Dyvik (2012), mens andre var i strid med dem. Spørreundersøkelsen ble til en viss grad brukt til å fremme hypoteser angående studentenes faktiske bruk av hunkjønnsformer.

Tekstundersøkelsen består av en analyse av genusmarkering av potensielle hunkjønnsord i studentenes stiler på tre forskjellige ferdighetsnivåer ${ }^{6}$. Siden stilene var av ulik lengde (henholdsvis 150-200, 350-400 og 550-600 ord), ble det valgt 57 stiler på begynnernivå, 29 på mellomavansert nivå og 20 på avansert nivå ${ }^{7}$. Det ble ekserpert alle forekomster av potensielt feminine ord ${ }^{8}$ som inneholdt en genusmarkering, i form av ubestemt artikkel i entall, bundet form entall eller possessivt pronomen. Nakne former og former med foranstilt possessivpronomen, samt flertallsformer, ble utelukket, siden de ikke inneholdt kjønnsmarkering.

I problemstillingen støtter jeg meg delvis på funnene til Ragnhilstveit (2009), og delvis på resultatene fra spørreundersøkelsen. Jeg stiller følgende hypoteser ang. de polske studentenes bruk av hunkjønnsmarkører:

1. Det vil være en korrelasjon mellom studentenes ferdighetsnivå i norsk og homogeniteten i deres bruk av hunkjønnsformer. Korrelasjonen vil bestå $i$ at studentene på begynnernivå er mindre konsistente i sin bruk av hunkjønnsmarkører enn de avanserte studentene. Dette skyldes større eksponering til norsk språkbruk, og dermed større bevissthet rundt dette emnet.

2. Studentene på begynnernivå vil bruke flere hunkjønnsmarkører enn de avanserte. Denne hypotesen stilles til tross for påstandene fremmet av Ranghildstveit (2009) omtalt i avsnitt 2. Dette skyldes flere årsaker, bl.a. de avanserte studentenes erfaring med norske avistekster, som i de fleste

\footnotetext{
${ }^{6}$ Stilene ble skrevet på norskeksamenene etter 1. og 3. år bachelorstudier, samt etter 5.år bachelorstudier/2. år masterstudier, noe som tilsvarer A2, B2/C1 og C2+ nivå i det europeiske rammeverket. I eksemplene nedenfor skal jeg bruke tallsymboler for å referere til hvilken tekst de kommer fra, der det første tallet står for nivå, og det andre tallet - for nummer av stilen. Dermed vil symbolet 1.33. stå for stil nummer 33 på begynnernivå, mens 5.3. for stil nummer 5 på avansert nivå.

${ }^{7}$ Ideelt sett burde det være 60 stiler på begynnernivå, 40 på mellomavansert nivå og 20 på det høyeste nivået.

${ }^{8}$ Jeg har valgt å utelukke substantiver med suffikset -het fra analysen, delvis fordi de fleste studentene anså hunkjønnsmarkerte het-substantiver som ukorrekte eller rare (se avsnitt 4.1.2), og delvis fordi de nesten alltid forekom i naken form, uten genusmarkering, i stilene.
} 
landsdekkende avisene er skrevet på moderat eller konservativ bokmål (jf. Dyvik, 2012). Bruk av hunkjønnsmarkører kan også være eksempel på transfer fra polsk som har et trekjønnet grammatisk system ${ }^{9}$.

3. Uansett nivå vil studentene helst bruke hunkjønnsmarkører på ord med biologisk kjønn, og da først og fremst personbetegnelser (men jf. punkt 1).

Det er også høysannsynlig at studentene på begynnernivå lærer visse former i faste fraser (som for eksempel nå for tida) og bruker dem uavhengig av den фvrige "formkonteksten". Dette fenomenet er imidlertid vanskelig å undersøke uten å føre en longitudinell studie av enkelte innlærere. Likevel skal jeg fors $\emptyset$ ke å peke på visse fraser der bruk av hunkjønnsformer trolig skyldes denne læringskonteksten.

\section{RESULTATENE}

\subsection{SPØRREUNDERSØKELSE}

Spørreunders $\varnothing$ kelsen ble besvart av 28 studenter på 2.år bachelorstudier (nivå B1/B2 i det europeiske rammeverket), og 8 på 1. år masterstudier (nivå C1/C2, som for enkelthetens skyld for betegnelse 4.år, i samsvaret med antall år de vanligvis hadde studert norsk). Antallet informanter tillater ikke å trekke bastante konklusjoner, men denne undersøkelsen var ment kun som et pekepinn for tekstunders $\varnothing$ kelsen som er presentert i avsnitt 4.2.

\subsubsection{ERKLART FORMBRUK}

Informantene på 2. år bachelorstudier var relativt enige i sin bruk av hunkjønnsformer. Det var kun ett tilfelle der informanten valgte kun hankjønnsformer, selv på substantivet kone, der hankjønnsformen er høyt markert. To av informantene brukte nesten utelukkende hankjønnsmarkører, med unntak av nettopp formen kona. Denne formbruken hører også til hva man kan klassifisere som konservativt bokmål. De øvrige informantene (over 70\%) tilskrev feminingenus til seks substantiver: bok, dør, uke, framtid, kone og datter. De abstrakte substantivene grense og makt, samt substantiver med suffikset -ing, ble nesten aldri valgt i sine hunkjønnsformer. Disse funnene kan tyde på at informantene til en viss grad er klar over at ikke alle av de potensielt feminine substantiver får hunkjønnsmarkering like ofte. Samtidig kan man se en viss forenkling $\mathrm{i}$ deres system, fordi begge personbetegnelsene får hunkjønnsmarkering nesten like ofte mens de i Dyviks (2012) undersøkelse ligger på to motsatte sider av spekteret. Det som er interessant å påpeke er den høye bruken av foranstilt artikkel $e i$.

\footnotetext{
${ }^{9}$ Samtidig er det verdt å peke på at denne studien ikke kan besvare spørsmålet om hvorvidt studentenes bruk av hunkjønnsmarkører skyldes transfer fra deres morsmål. For å kunne drøfte det bør man inneholde én eller flere kontrollgrupper med andre morsmål, helst med forskjellige grammatiske kjønn, og på forskjellige ferdighetsnivåer.
} 
Blant informantene på 1.år master var det én person som konsekvent valgte bare hunkjønnsmarkerte former, og én som hadde en motsatt strategi, dvs. valgte kun hankjønnsmarkering, selv på substantivet kone. Blant de øvrige informantene er det observert samme tendenser som hos de mindre avanserte studentene: hunkjønnsformene med høyest frekvens er kona og dattera. Formen framtida er valgt av fem informanter, men den andre tidsbetegnelsen, ei uke, blir valgt kun av to. En lignende tendens kan vi se for substantivene bok og $d \phi r$ som i ubestemt form med foranstilt artikkel $e i$ blir valgt av henholdsvis fire og to informanter. Disse funnene tyder på at de mer avanserte norskinnlærere er mer klar over den noe svakere bruken av foranstilt artikkel $e i$ i forhold til den bundne a-formen, enn deres mindre avanserte kolleger.

\subsubsection{BEVISSTHET OM IMPLIKASJONSFORHOLD I BRUK AV HUNKJØNNSMARKØRER}

Den andre delen av spørreundersøkelsen besto av en vurdering av 7 setninger, og hadde til hensikt å måle studentenes bevissthet rundt bruken av hunkjønnsmarkører. Informantene skulle vurdere setningene som ukorrekte (A), korrekte men unaturlige (B) eller korrekte og naturlige (C), samt foreslå en korrigering. Resultatene er framstilt i tabell $4^{10}$.

\begin{tabular}{|c|c|c|c|c|c|c|c|c|c|c|}
\hline & \multicolumn{2}{|c|}{$\mathbf{A}$} & \multicolumn{2}{|c|}{ A-FEIL } & \multicolumn{2}{|c|}{ B } & \multicolumn{2}{|c|}{ B-FEIL } & \multicolumn{2}{|c|}{$\mathbf{C}$} \\
\hline SETNING & id & 先 & 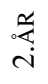 & 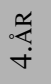 & is & 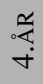 & is & 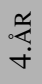 & त. & 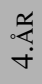 \\
\hline $\begin{array}{l}\text { *1.Ser du denne kvinna der borte } \\
\text { ved døren? }\end{array}$ & 1 & 0 & 0 & 0 & 2 & 2 & 1 & 1 & 24 & 5 \\
\hline $\begin{array}{l}\text { *2.Nå for tiden er regjeringa streng } \\
\text { med asylsøkere. }\end{array}$ & 2 & 0 & 1 & 0 & 7 & 4 & 5 & 1 & 13 & 3 \\
\hline $\begin{array}{l}\text { 3.Løsninga til problemet blei funnet } \\
\text { i løpet av helga. }\end{array}$ & 4 & 0 & 0 & 0 & 12 & 3 & 3 & 2 & 9 & 3 \\
\hline $\begin{array}{l}\text { 4.De sto og snakket på gaten til midt } \\
\text { på natta. }\end{array}$ & 0 & 0 & 3 & 1 & 6 & 2 & 1 & 0 & 20 & 5 \\
\hline $\begin{array}{l}\text { *5.Mora mi tilbrakte sin ferie på hytten } \\
\text { vår i Rondane. }\end{array}$ & 0 & 0 & 0 & 0 & 13 & 3 & 3 & 1 & 12 & 4 \\
\hline 6.Denne muligheta har vi ikke tenkt på. & 3 & 2 & 1 & 0 & 18 & 3 & 3 & 2 & 3 & 1 \\
\hline 7.Jenta satt på kafeen og leste avisen. & 0 & 0 & 0 & 0 & 4 & 1 & 1 & 0 & 23 & 7 \\
\hline
\end{tabular}

(Tab. 4) Fordeling av informantenes vurderinger av de 7 setningene i spørreskjemaet ${ }^{\prime \prime}$.

${ }^{10}$ I alle tabellene som framstiller resultatene av undersøkelsene valgte jeg å bruke absolutte tall. Jeg mener det gjør resultatene enklere å lese fra tabellen. Likevel benytter jeg med av prosenttall i teksten.

${ }^{11}$ Bokstavene ABC i linjen øverst står for de ulike valgmulighetene, mens gruppen A-feil og B-feil står for vurderingene som manglet korrigeringsforslag eller som fokuserte på andre aspekter enn hunkjønnsmarkering (for eksempel ordstilling eller preposisjonsvalg). 
Setningene markert med * inneholder ukonsekvent bruk av hunkjønnsformer ifølge Dyvik (2012). Blant disse blir setning 1 vurdert av det store flertallet som korrekt. Dette kan tyde på at hunkjønnsform på personbetegnelser virker naturlig for informantene. Setningene 2 og 5 blir mindre entydig vurdert, og omtrent halvparten av informantene i begge grupper oppfatter setningene som unaturlige. Setningene som oftest ble vurdert som unaturlige eller ukorrekte er setning 3 og 6 . Disse setningene er faktisk er korrekte, men de inneholder en hunkjønnsform av substantivet med suffiks -het og den radikale formen av preteritum blei istedenfor den mer vanlige ble. Disse formene er godkjent av bare et fåtall informanter.

Spørreundersøkelsen tyder på at studentene på begge nivåene kun til en viss grad er klare over implikasjonsforhold mellom feminine former av substantiv. Ofte ser de at det er noe unaturlig ved setningens formbruk, men er ikke helt sikre på hvilken korrigering de kan foreslå. I sine vurderinger benytter informantene seg heller av frekvenskriterium, og anser formene som sjelden forekommer som unaturlige eller ukorrekte ${ }^{12}$.

\subsection{TEKSTUNDERS $\varnothing K E L S E$}

Til sammen ble det analysert 403 forekomster av potensielt feminine substantiver, og 104 av disse (24\%) med foranstilt artikkel en eller ei. Blant disse er den feminine artikkelen ei brukt i omtrent $26 \%$ av forekomster. Blant de 299 bundne former er derimot 164 markert for hunkjønn, noe som utgjør $55 \%$. Det helhetlige bildet er altså at den bundne hunkjønnsformen med suffikset $-a$ brukes heller enn den foranstilte artikkelen $e i$. Dette funnet virker å være i samsvar med den norske språkbruken (Faarlund m.fl., 1997:152).

\subsubsection{INTRA-BRUKERHOMOGENITET}

For å måle intra-brukerhomogenitet ble alle stilene undersøkt hver for seg, med tanke på om de samsvarer med det ovenfornevnte systemet av implikasjonsforhold mellom de ulike hunkjønnsformene. Stilene ble klassifisert i tre grupper:

(A) de som ikke inneholdt noen som helst hunkjønnsformer,

(B) de som inneholdt hunkjønnsformer i samsvar med systemet, og

(C) de som inneholdt hunkjønnsformer som var i strid med systemet.

${ }^{12}$ Studentene fikk undersøkelsen med kommentarene kun på polsk (i vedlegget er de oversatt til norsk). Det var et bestemt valg som skulle forsikre meg om at studentene forsto hva de ble bedt om. Samtidig er det umulig å si om informantene ikke tolket adjektivet naturalny 'naturlig' som zwyczajny 'vanlig'. 
Som eksempler kan vi nevne bruk av følgende substantivformer i samme tekst: ei kvinne - på gaten (stil 1.10), mora mi - en deilig kake (1.45) og mora mien uke siden (3.22). Til denne gruppen hører også bruk av to ulike markører på samme lemma, som: ei kvinne - en kvinne (5.3), ei kvinne - kvinnen (5.4), hele tida - på tiden (3.29), og en blanding av konservativ rot og en moderat (radikal?) endelse i en sammensetning: fremtida (3.15).

Siden systemet kartlagt av Dyvik (2012) er begrenset til 60 lemma, oppstår det noen tvilstilfeller. Disse ble konfrontert med en hjemlig språkbruker sine intuisjoner ${ }^{13}$, og etterpå tilskrevet en konkret gruppe.

Hos den mest avanserte gruppen er det tre stiler som er klassifisert i gruppe $\mathrm{C}$, noe som gir et homogenitetsnivå på $85 \%$. Noen av avvikene kan muligens forklares med avstand mellom artikkel og selve ordet, som i følgende eksempler:

(2) ei kvinne - en stor, varm og fruktbar kvinne

(3) ei jente - en pen jente

I samme gruppe inneholder 9 av stilene ingen hunkjønnsmarkerte former, mens 8 forfattere benyttet seg av hunkjønnsmarkører på en konsekvent måte. Hvis man altså regner homogeniteten kun blant de innlærere som i det hele tatt bruker hunkjønn, er den mye lavere og ligger på $62,5 \%$.

Hos den mellomavanserte gruppen finner vi et lignende, om noe høyere homogenitetsnivå på 86,2\% (4 stiler av 29 hører til gruppe C). 14 stiler inneholder ingen hunkjønnsmarkering, mens 11 benytter seg av noen former som er i samsvar med forventningene. Hvis man da ser kun på de innlærerne som bruker hunkjønn er homogenitetsnivået på $73 \%$.

Gruppen på begynnernivå skiller seg ikke fra de øvrige gruppene når det gjelder homogenitetsnivå som ligger på 86\% (8/57 i gruppe C). Her er det likevel iøynefallende at det store flertallet (41/57) av stiler inneholdt flere hunkjønnsformer av de potensielt feminine substantiver, og mange av dem utelukkende dem. Kun 8 stiler på dette nivået ble klassifisert som gruppe A (mot nærmest halvparten i begge de mer avanserte gruppene). Hvis man utelukker dem fra statistikken får vi et homogenitetsnivå på 83,5\%.

\subsubsection{INTRA-GRUPPETENDENSER}

Hos den mest avanserte gruppen norskinnlærere står hunkjønnsformer for $20 \%$ av alle forekomster i bundet form, og $19 \%$ av alle forekomster med foranstilt artikkel. I den mellomavanserte gruppen er resultatene $34 \% \mathrm{i}$ bundet form og $12 \%$ med foranstilt artikkel. Hos nybegynnere er tallene veldig forskjellige, med $84 \%$ i bundet form og $47 \%$ med foranstilt artikkel. Man kan

\footnotetext{
${ }^{13}$ Her vil jeg takke Espen Iden for hjelp.
} 
altså se en stor skille mellom nybegynnere og de to mer avanserte gruppene i bruk av femininum. Som allerede sagt inneholdt mange av stilene på begynnernivå først og fremst feminine former. Dette kan skyldes temaene for stilene på begynnernivå, som ofte handler om konkrete ting, hverdagslige opplevelser eller personer, og sjelden om abstrakte forhold. Dessuten inneholdt stilene på begynnernivå tallrike tidsuttrykk (klokka, uka, helga) som ofte ble gjentatt og sørget for et høyt antall feminine substantiver. Delresultatene presentert i neste avsnitt vil belyse hvilke typer ord som oftest forekommer i hunkjønn.

\subsubsection{DELRESULTATER I ULIKE SUBSTANTIVGRUPPER}

Personbetegnelser (54 forekomster i tekstene)

\begin{tabular}{|c|c|c|c|c|}
\hline GRUPPE & $\begin{array}{c}\text { BUNDET FORM } \\
\text {-EN }\end{array}$ & $\begin{array}{c}\text { FORANSTILT } \\
\text { EN }\end{array}$ & $\begin{array}{c}\text { BUNDET FORM } \\
\text {-A }\end{array}$ & $\begin{array}{c}\text { FORANSTILT } \\
\text { EI }\end{array}$ \\
\hline $5 . \AA \mathrm{R}$ & 2 & 4 & 2 & 7 \\
\hline $3 . \AA \mathrm{R}$ & 0 & 1 & 3 & 2 \\
\hline $1 . \AA \mathrm{R}$ & 1 & 1 & 25 & 6 \\
\hline
\end{tabular}

(Tab. 5) Forekomster av personbetegnelser (mor, sфster, datter, jente, kone, dame o.a.) i hunkjønnsform, fordelt på de ulike nivåene.

I denne gruppen er det store flertallet av forekomster brukt i hunkjønnsform. I de to mest avanserte gruppene er ordet kvinne dominerende, mens informantene på begynnernivå bruker også ofte familieord som mor og søster. I denne gruppen finner vi også mange fraser med etterstilt possessivpronomen som venninna mi eller kona si. Det som er spesielt interessant er den høye frekvensen av hunkjønnsmarkert kvinne, et ord som hører til de mest markerte når brukt i femininum. Dessuten bruker to av de mest avanserte informantene den ubestemte artikkelen ei i enkle substantivfraser (ei jente, ei kvinne), men artikkelen en i fraser med utfylling (en pen jente, en stor, varm og fruktbar kvinne). Dette kan tyde på at avstanden mellom bestemmeren og kjernen $\mathrm{i}$ en gitt frase kan ha påvirkning på kongruens i denne, en påstand ellers fremmet av Bock \& Miller (1991) og Haskell \& MacDonald (2005).

Konkrete substantiver (65)

\begin{tabular}{|c|c|c|c|c|}
\hline GRUPPE & $\begin{array}{c}\text { BUNDET FORM } \\
\text {-EN }\end{array}$ & $\begin{array}{c}\text { FORANSTILT } \\
\text { EN }\end{array}$ & $\begin{array}{c}\text { BUNDET FORM } \\
\text {-A }\end{array}$ & $\begin{array}{c}\text { FORANSTILT } \\
\text { EI }\end{array}$ \\
\hline $5 . \AA ̊ \Omega$ & 3 & 5 & 6 & 0 \\
\hline $3 . \AA R$ & 2 & 1 & 2 & 2 \\
\hline $1 . \AA \mathrm{R}$ & 6 & 7 & 23 & 8 \\
\hline
\end{tabular}

(Tab. 6) Forekomster av substantiver med konkret referanse (bok, avis, dфr, gate o.a.) i hunkjфnnsform, fordelt på de ulike nivåene. 
De vanligste konkrete substantivene som forekommer i hunkjønnsform i de mer avanserte gruppene er gate og jord, mens på begynnernivå dominerer substantivene bok, avis, seng og hånd. Også i denne gruppen ser vi at hunkjønnsformer er dominerende, men i mindre grad enn når det gjaldt personbetegnelser. Der kunne man tydelig se overtaket av hunkjønnsformer hos alle informantene, mens her er tallene like for hunkjønns- og hankjønnsformer hos de to mest avanserte gruppene. Det er også flere forekomster av hankjønnsformer hos innlærere på begynnernivå.

Abstrakte substantiver (73)

\begin{tabular}{|c|c|c|c|c|}
\hline GRUPPE & $\begin{array}{c}\text { BUNDET FORM } \\
\text {-EN }\end{array}$ & $\begin{array}{c}\text { FORANSTILT } \\
\text { EN }\end{array}$ & $\begin{array}{c}\text { BUNDET FORM } \\
\text {-A }\end{array}$ & $\begin{array}{c}\text { FORANSTILT } \\
\text { EI }\end{array}$ \\
\hline $5 . \AA \mathrm{R}$ & 22 & 12 & 1 & 0 \\
\hline $3 . \AA \mathrm{R}$ & 20 & 6 & 4 & 0 \\
\hline $1 . \AA \mathrm{R}$ & 5 & 2 & 0 & 1 \\
\hline
\end{tabular}

(Tab. 7) Forekomster av substantiver med abstrakt referanse (makt, sak, grense, årsak, glede o.a.) i hunkjønnsform, fordelt på de ulike nivåene.

Abstrakte substantiver blir som forventet mer frekvent i takt med $\varnothing$ kende språkferdigheter. De blir ytterst sjelden brukt i hunkjønnsform, og de ordene som forekommer med a-endelse er side, lønn, helse og en sammensetning prioritetsliste. Dessuten er det en forekomst av den ubestemte artikkelen $e i$ sammen med substantivet kraft.

Substantiver med suffikset -ing (92)

Denne gruppen substantiver har et høyt antall forekomster og er klart den mest homogene av alle når det gjelder bruk av genusmarkører - man finner altså ingen hunkjønnsformer. Dette er i samsvar med spørreundersøkelsen, der substantivene med suffikset -ing ble av alle informantene med unntak av én tilskrevet maskulint genus. Interessant nok plasseres ing-substantivene i Dyviks (2012) undersøkelse på to ulike nivåer, der a-formen på de mer abstrakte substantivene lфsning og utfordring impliserer a-form på de mer konkrete trening og melding. I de analyserte stilene er denne forskjellen ikke synlig.

Tidsuttrykk (119)

Denne gruppen substantiver ble skilt ut av to grunner: de var veldig frekvente, men de passet også bra som eksempler på faste innlærerfraser. 


\begin{tabular}{|l|c|c|c|c|}
\hline & $\begin{array}{c}\text { BUNDET FORM } \\
\text {-EN }\end{array}$ & $\begin{array}{c}\text { FORANSTILT } \\
\text { EN }\end{array}$ & $\begin{array}{c}\text { BUNDET FORM } \\
\text {-A }\end{array}$ & $\begin{array}{c}\text { FORANSTILT } \\
\text { EI }\end{array}$ \\
\hline $5 . \AA \mathrm{R} R$ & 9 & 0 & 8 & 0 \\
\hline $3 . \AA \mathrm{R}$ & 1 & 1 & 13 & 0 \\
\hline $1 . \AA \mathrm{R}$ & 17 & 3 & 98 & 1 \\
\hline
\end{tabular}

(Tab. 8) Forekomster av substantiver med tidsreferanse (tid, framtid, uke, klokke, helg o.a.) i hunkjønnsform, fordelt på de ulike nivåene.

I begynnergruppen er det høye antallet forekomster forårsaket av ord som klokke og uke brukt som tidsadverbialer som ofte gjentok seg flere ganger i samme tekst, og står for henholdsvis 19 og 21 forekomster. Disse konstruksjonene hører sannsynligvis til faste innlærerfraser som alltid brukes i samme form, i dette tilfellet - hunkjønn. I de to mer avanserte gruppene forekommer kun ordet tid og dets sammensetninger som framtid, fortid og vikingtid. Interessant nok blir tid oftere oppfattet som hankjønn når det står alene enn når det danner en sammensetning, og denne tendensen er synlig på alle de tre nivåene. Blant sammensetningene med tid har vi kun to forekomster av hankjønn, mot 26 av hunkjønn, mens for det frittstående ordet tid er fordelingen 15 mot 16. Dette er i samsvar med Dyviks (2012) funn, der formen framtida er mindre markert enn formen tida.

Det er sannsynlig at en del av de analyserte forekomstene av ordet tid, særlig der det inngår i preposisjonsfrase (f.eks. med/for tiden), også hører til faste innlærerfraser. I dataene kan man likevel ikke finne en bekreftelse på denne hypotesen, for tid blir i denne konteksten like ofte tilskrevet hankjønn som hunkjønn.

\section{DISKUSJON}

Til grunn for denne studien lå det noen hypoteser og generelle spørsmål som jeg nå kan forsøke å besvare.

Hypotese 1 ang. korrelasjon mellom språkferdigheter og homogenitetsnivået ble avkreftet. Det har vist seg at studentene på alle nivåene hadde et ganske høyt homogenitetsnivå på over $80 \%$. Samtidig, hvis man tar i betraktning kun studentene som i det hele tatt bruker hunkjønn i sine tekster, ser man at det faktisk er studentene på begynnernivå som bruker hunkjønn mest konsekvent, mens de mest avanserte studentene viser flest avvik. Disse resultatene er til en viss grad overraskende, men kan kanskje tyde på at de mest avanserte studentene sliter med konsekvent bruk av hunkjønn slik som morsmålsbrukere gjør ifølge Tønnessen (2009:250).

Hypotese $2 \mathrm{om}$ at studentene på begynnernivå bruker flere hunkjønnsmarkører enn de mer avanserte ble bekreftet. Det er ikke lett å redegjøre for grunnene til det. På den ene siden kan man påstå at den høye 
frekvensen av hunkjønnsmarkerte substantiver til en viss grad kan skyldes emnene som omtales i tekstene. Studentene på begynnernivå skriver oftere om hverdagslige ting, som deres familie eller fritidsaktiviteter, mens de mer avanserte omtaler heller abstrakte forhold. Sjangermessig er det også en stor forskjell på de analyserte stilene, med deskriptive tekster på lavere nivå og drøfteoppgaver på høyere nivå. Det har uten tvil påvirkning på valg av ordene og da på resultatene. Dessuten kan man anta at morsmålstransfer er sterkere hos innlærere på begynnernivå enn hos de mer avanserte. Hvorvidt funnene kan attribueres til morsmålstransfer fra polsk er imidlertid umulig å besvare uten en kontrollgruppe. Sist, men ikke minst må man referere til Ragnhildstveit (2009) påstand om underrepresentasjon av maskulinum i andrespråkstekster. Hennes studie er imidlertid utført på materialet som består av andrespråkstekster på B1-nivå og høyere (ibid.:55). I denne studien er det informantene på begynnernivå (A2-nivå) som bruker flest feminine markører (opp til $84 \%$ av alle potensielt feminine substantiver), mens de to mer avanserte grupper bruker dem mye sjeldnere. Imidlertid virker ikke forskjeller i generelle språkferdigheter som en plausibel forklaring til så store avvik i formvalget. Derfor er det rimelig å påstå at både morsmålstransfer og oppgaveformuleringen kan ha påvirkning på bruk av hunkjønnsmarkører hos de polske norskinnlærerne.

Det som er mest interessant er ordene som relativt ofte dukker opp på alle nivåene, dvs. personbetegnelser og tidsuttrykk. Mens de fleste substantivene analysert som tidsuttrykk befinner seg i midten av Dyviks (2012) skala av markerthet, ligger personbetegnelsene på to motsatte sider, med mor og kvinne som høyt markert i hunkjønnsform, og jente som høyt markert i hankjønnsform. Analysen tyder på at det andre forholdet er studentene ubevisst på. De fleste eksempler på ukonsekvent bruk av hunkjønnsmarkører skyldes også "feil" i personbetegnelser. Dette leder til hypotese 3 som handler om bruk av hunkjønnsmarkører nettopp i denne gruppen substantiver. Både tekstanalysen og spørreundersøkelsen tyder på at personer med biologisk hunkjønn vanligvis blir tilskrevet grammatisk hunkjønn. Tendensen er noe sterkere hos de mindre avanserte studentene, men selv de mest avanserte studentene brukte mange hunkjønnsmarkører i denne gruppen substantiver. Man kan altså si at hypotese 3 ble bekreftet, noe som for $\varnothing v$ vrig stemmer overens med funnene til Ragnhildtveit (2009).

Hvis man ser bort fra de enkelte eksemplene på ukonsekvent bruk av hunkjønn, samt personbetegnelsene, stemmer de polske innlærernes språkbruk stort sett med tendensene som observeres i norsk. Det er altså vanligere å bruke hunkjønn på konkrete substantiver enn på abstrakte, og hunkjønnsformene av substantiver med suffiksene -ing og -het forekommer relativt sjelden. Dette resultatet er også i tråd med studentenes erklærte språkbruk. Samtidig har spørreunders $\emptyset$ kelsen vist at studentene ikke er 
bevisste på at visse form henger sammen. De er med andre ord sannsynligvis ikke klare over de ulike subvarietetene, eller stilene, som finnes i bokmål.

\section{KONKLUSJONER OG SPØRSMÅL TIL VIDERE DRØFTING}

Det er ikke lett å besvare spørsmålet stilt i tittelen om polske norskstudenter er konservative eller ei i sin språkbruk. Både spørreunders $\varnothing$ kelsen og tekstanalysen tilsier at studentene generelt bruker mange hunkjønnsmarkører på begynnernivå, og blir mindre radikale jo høyere ferdighetsnivå de oppnår i norsk, uten at de nødvendigvis er klar over det. Samtidig finnes det noen få tilfeller av veldig tydelige tendenser til å unngå å bruke femininum i det hele tatt, og på den motsatte siden - å bruke hunkjønnsmarkører på alle potensielt feminine ord. Likevel plasserer de fleste seg et sted i midten, men noen få feminine markører på konkrete ord og personbetegnelser. Dette kan også skyldes at:

moderate Bokmål is more of a real, identifiable subvariety of Bokmål than radical Bokmål, which may be more of an abstraction in the sense that it refers to the sum of possible departures from moderate Bokmål without itself being a subvariety about which language users tend to have consistent intuitions. (Dyvik, 2012:201)

Studien viser at polske norskinnlærere velger å være på den trygge siden og å bevege seg i den mer reelle (mer kjente?) moderate varianten av bokmål, enn å risikere å bruke formene som de naturligvis ikke kan ha noen konsekvente intuisjoner om.

Studien er på ingen måte uttømmende for dette omfattende emnet. For å besvare spørsmål som kom opp som følge av denne studien ville det være formålstjenlig å utføre en longitudinell studie som innebar samme informanter og forskjellige teksttyper unders $\varnothing \mathrm{kt}$ i takt med deres $\emptyset$ kende språkbeherskelse og stadig større eksponering til norsk språkbruk. En undersøkelse av hunkjønnsformer brukt av innlærerne i talespråket ville muligens være bedre egnet til å besvare transferspørsmålet, i og med at man i en samtale er nødt ta raskere og mer intuitive valg, mens man i skriftformen kan gå tilbake og forandre sine formvalg selv en god stund etter at den første avgjørelsen ble tatt. Dessuten hadde det vært interessant å undersøke bruk av hunkjønnsmarkører i norsklærebøker, for da ville man kunne til en viss grad peke på noen av grunnene til studentenes språkvalg. Et annet fenomen som virker spennende å utforske er bruk av hunkjønnsmarkører i sammensetninger. Som analysen har vist følger frittstående leksemer og deres sammensetninger forskjellige mønstre når det gjelder genustildeling. Kan forholdet mellom tid og framtid, omtalt i kapittel 4.2.3. "oversettes" til par som kraft-arbeidskraft 
eller liste-prioritetsliste? Dessuten er det en rekke andre stammeformer (eller stavevarianter) og grammatiske markører som også inngår i systemet av subvarieteter av både bokmål og nynorsk. For å danne et helhetlig bilde av det norske språket burde man kartlegge hvilke implikasjonsforhold som ligger bar bruken av formene bygget eller bygde, eller bak bruken av diftonger i ordene aleine og stein. Den demokratiske, eller elitistiske, valgfriheten gjør den type studier veldig krevende, men samtidig nødvendig for andrespråksbrukere, særlig i lys av resultatene fra Glahn m.fl. (2001) om at genus er sist mestret av alle nominale kategorier. Uklarheter knyttet til bruk av hunkjønn i bokmål hjelper sikkert ikke til å gjøre denne kategorien lettere å tilegne.

\section{REFERENCER}

Bock, K., Miller, C. (1991). Broken Agreement. Cognitive Psychology 23, 45-93.

Dyvik, H. (2009). Å navigere i skriftspråkets rom. Om normklynger i bokmål og nynorsk. Språknytt 3, 18-21.

Dyvik, H. (2012). Norm clusters in written Norwegian. In G. Andersen (ed.) Exploring newspaper language (s. 193-219). Amsterdam/New York: John Benjamins.

Eek, Ø. (2009). Tre ordlister med uoffisiell normering - og sammenhengen de står i: Aftenpostens rettskrivningsordliste (2006), NTB-språket (2007) og Riksmålsordlisten (2007). In H. Omdal, R. Røsstad (eds.) Språknormering - i tide og utide? (s. 123-130). Oslo: Novus forlag.

Faarlund, J. T., Lie, S., Vannebo, K. I. (1997). Norsk referansegrammatikk. Oslo: Universitetsforlaget.

Glahn, E., Håkansson, G., Hammerberg, B., Holmen, A., Hvenekilde, A., Lund, K. (2001). Processability in Scandinavian second language acquisition. Studies in Second Language Acquisition 23 (3), 389-416.

Haskell, T., MacDonald, M. (2005). Constituent Structure and Linear Order in Language Production: Evidence from Subject-Verb Agreement. Journal of Experimental Psychology: Learning, Memory, and Cognition 31 (5).

Horbowicz, P. (2011). Norskkompetanse som navigasjonskunst. Folia Scandinavica Posnaniensia 12, 103-113.

Jahr, E.H. (1994). Utsyn over norsk språkhistorie etter 1814. Oslo: Novus Forlag

Jahr, E.H., Mæhlum, B. (eds.) (2009). Norsk lingvistisk tidsskrift 1/2009. Spesialnummer om standard talemål.

Omdal, H. (1999). Språklig toleranse og språklig mangfold. Språknytt 3/4, 4-11.

Ragnhildstveit, S. (2009). Genustildeling og morsmålstransfer $i$ norsk mellomspråk. En korpusbasert studie. Upublisert masteroppgave ved Institutt for lingvistiske, litterære og estetiske studier, Universitetet i Bergen.

Rosén, V., de Smedt, K. (2000). Er korrekturlesingsevnen di god? Resultater fra SCARRIE. In O. J. Westvik (ed.) Nordlyd: Troms $\varnothing$ University working papers of language and linguistics 28, 214-228.

Sandøy, H. (2009). Standardspråk - kultur og ukultur. In H. Omdal, R. Røsstad (eds.) Språknormering - i tide og utide? (s. 215-228). Oslo: Novus forlag.

Trudgill, P. (1997). Norwegian as a Normal Language. In U. Røyneland (ed.): Language Contact and Language Conflict. Proceedings of The International Ivar Aasen Conference, 14-16 November 1996, Volda College, Volda, 151-158. 
Tønnessen, R. (2009). Kva kan vi gjera med ulempene som følger med valfridomen? In H. Omdal, R. Røsstad (eds.) Språknormering - i tide og utide? (s. 241-254). Oslo: Novus forlag.

Vagstein, A. (2009). Hvor mange genus har norsk? En diskusjon om genusinndelingskriterier. Upublisert masteroppgave ved Institutt for lingvistiske og nordiske studier, Universitetet i Oslo.

Uri, H.(2001). Genusmarkering og hemmelighetskremmeri. In A. Golden, H. Uri (eds.) Andrespråk, tospråklighet, norsk. Festskrift til Anne Hvenekilde (s. 30-44). Oslo: Unipub forlag.

\section{VEDLEGG. SPØRREUNDERSØKELSEN}

I. Której z tych form chętniej użył(a)byś we własnym tekście?

Hvilken av disse formene ville du helst bruke i din egen tekst?

$\square$ utfordringen
$\square$ en sten
$\square$ bygde
$\square$ ei bok
$\square$ makten
$\square$ aleine
$\square$ kona
$\square$ ei løsning
$\square$ snakket
$\square$ datteren
$\square$ skrev
$\square$ framtiden
$\square$ en dør
$\square$ et gulv
$\square$ grensen
$\square$ laget
$\square$ ei uke

$\square$ utfordringa
$\square$ en stein
$\square$ bygget
$\square$ en bok
$\square$ makta
$\square$ alene
$\square$ konen
$\square$ en løsning
$\square$ snakka
$\square$ dattera
$\square$ skreiv
$\square$ framtida
$\square$ ei dør
$\square$ et golv
$\square$ grensa
$\square$ lagde
$\square$ en uke

II. Oceń poniższe zdania. Jeżeli wybrałeś opcję A lub B, popraw zdanie tak, by można było je zaklasyfikować do grupy C.

Vurder setningene nedenfor. Hvis du har valgt A eller B, korriger setningen slik at den kan klassifiseres som C.
A. zdanie niegramatyczne B. zdanie poprawne ale nienaturalne
C. zdanie poprawne i naturalne
A. ugrammatisk
B. grammatisk men ikke naturlig
C. grammatisk og naturlig

1. Ser du denne kvinna der borte ved døren?

A

$\mathrm{B}$

C. $\square$

2. Nå for tiden er regjeringa streng med asylsøkere.

A. $\square$ B.

C.

3. Løsninga til problemet blei funnet i løpet av helga.

A. $\square$ B.

C. 
4. De sto og snakket på gaten til midt på natta.

A. $\square$ B.

B. $\square$ C. $\square$

5. Mora mi tilbrakte sin ferie på hytten vår i Rondane.

A. $\square$ B.

C.

6. Denne muligheta har vi ikke tenkt på.

A. $\square$ B.

C.

7. Jenta satt på kaféen og leste avisen.

A.

B.

C.

\section{Paulina Horbowicz}

Uniwersytet im. Adama Mickiewicza w Poznaniu

Katedra Skandynawistyki

al. Niepodległości 4

61-874 Poznań

Poland

phorbo@amu.edu.pl 